\title{
1 Single nucleotide polymorphism of candidate genes in non-descript \\ 2 local goats of Sri Lanka
}

3

4

5 H B P C Ariyarathne ${ }^{\mathrm{a}}$, H B S Ariyaratne ${ }^{\mathrm{a}}$ and L G S Lokugalappatti ${ }^{\mathrm{a}}$ *

6 8 9

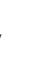

3

4

5

6

7

8

${ }^{\text {a }}$ Department of Basic Veterinary Sciences, Faculty of Veterinary Medicine and Animal Science, University of Peradeniya, Peradeniya 20400, Sri Lanka.

*Corresponding Author: L G S Lokugalappatti (slokug@pdn.ac.lk), Tel +94 812395806 


\section{Abstract}

32 In the present study, genetic polymorphism in exon 4 of kappa casein ( $k$-CSN3), exon 2-3 of 33 alpha lactalbumin $(L A L B A)$ and exon 1 of gonadotropin releasing hormone receptor $(G n R H R)$ 34 genes were analyzed as candidate genes for milk production, milk quality and prolificacy aiming 35 to provide information for future studies on genetic improvements in non-descriptive local goats in Sri Lanka. Altogether eleven, thirteen and three single nucleotide polymorphisms (SNPs) were

37 identified in $k-C S N 3, L A L B A$ and $G n R H R$ gene fragments respectively utilizing the DNA 38 sequencing technique in Sri Lanka. Seven polymorphic sites out of eleven in $k$-CSN3 gene fragment and the recorded polymorphic site in exon 3 of $L A L B A$ gene fragment were homozygous while all three polymorphic sites in GnRHR gene fragment were heterozygous.

41 Two of the SNPs recorded in the present study are found to unique for Sri Lankan non-descript goat population at $\mathrm{G} 203 \mathrm{~T}$ and $\mathrm{A} 730 \mathrm{G}$ in $k-C S N 3$ and GnRHR genes respectively. The study records another two SNPs in GnRHR gene which are already known to be correlated with higher fecundity in goats (G757A and G891T). Results of the present study will be extremely important in future attempts to indicate markers to improve the milk production, composition of milk and litter size of non-descript local goats in Sri Lanka.

47 Key words; non-descript local goats, $k-C S N 3, L A L B A, G n R H R$, SNPs, DNA sequencing Introduction

49 Sri Lankan non-descript local goats are highly localized, heterogeneous group which covers the majority of the goat population in the country (National Livestock Breeding Policy 2010) and are currently known to be under the threat of extinction due to intensive cross breeding with exotic breeds (Silva 2010). These non-descript goats are much more important at local circumstances as they hold invaluable genetic resources for high adaptability to local environmental conditions, 54 disease resistance (Silva 2010) and high degree of prolificacy (National Livestock Breeding Policy 2010) though, they are poor in production parameters compared to exotic breeds (Silva 2010). Low performance in production of non-descript goats may be the result of poor 57 management practices in rural areas and genetic makeup of animals (Azevedo et al. 1994). 58 However, SNPs in production related genes affect significantly on the phenotypic characters 59 though they arise at a lower rate in a population (Cargill et al. 1999) and production parameters 60 can be greatly enhanced at a minor cost by promoting the inheritance of these beneficial 61 mutations to next generation via selection. Consequently, modern researches are at an inspired 
interest on association analysis of SNPs and related phenotypic characters such as milk, meat and

63 wool production and prolificacy traits. $k$-CSN3 and LALBA genes are milk trait related and

$64 G n R H R$ is a fecundity trait related gene which are collectively widely studied genes for genetic

65 variability. Many researchers have reported the association between $k$-CSN3 genetic variability

66 and milk composition (Chiatti et al. 2005, Marletta et al. 2007) and milk production (Marletta et

67 al. 2007). Further studies have revealed the association between $L A L B A$ gene polymorphism and

68 nutrient content of milk (Lan 2007, An 2009, Zidi 2014) and relationship between genetic

69 variability of GnRHR gene and prolificacy trait (Ming-Xing et al. 2009, Yang et al. 2011). The

70 inclusive goal of this study was to identify SNPs in Caprine k-CSN3, LALBA and GnRHR genes

71 aiming to genetically characterize non-descript local goats of Sri Lanka, thereby to offer genetic

72 clues for future association analysis.

\section{Material and methods}

\section{Collection of samples}

75 A sample of 112 non-descript local goats from Eastern (49), Northern (15), Northwestern (37),

76 and Southern (11) provinces was used for the study to cover different localities of Sri Lanka.

77 Blood was collected from animals into sterile vacutainer tubes containing $100 \mu \mathrm{g} / \mathrm{ml}$ Ethylene

78 diammine tetraacetic Acid (EDTA) using jugular puncture method.

79 Extraction, PCR amplification and Sequencing of DNA

80 DNA extraction from collected blood samples was done using salting-out protocol (Jawdat et al.,

81 2011) and commercially available kits (Wizard Genomic DNA Purification Kit). Extracted 82 genomic DNA was visualized on Ethidium bromide stained $1 \%$ agarose gels and quantified 83 using a DNA spectrophotometer (BIOMATE 3). Exon 2-3 of Caprine LALBA (part of exon 2, 84 intron 2 and part of exon 3) (667 bp), exon 4 of $k$-CSN3 (458 bp) and exon 1 of GnRHR (746 bp) 85 gene fragments were amplified using already published protocols by Jain et al., 2009; Kiplagat et 86 al., 2010 and Yang et al., 2011 respectively. PCR was performed in a $25 \mu 1$ reaction mixture 87 containing $50 \mathrm{ng}$ genomic DNA, $0.5 \mu \mathrm{M}$ of each primer, $1 \times$ PCR reaction buffer, $1.5 \mathrm{mM}$ of $88 \mathrm{MgCl} 2,200 \mu \mathrm{M}$ of dNTPs and 0.625 units of Taq DNA polymerase and amplifications were carried out in an ABI2720 (Applied Biosystems ${ }^{\circledR}$ ) Thermal Cycler. Amplified PCR products 90 were then visualized on $1 \%$ Agarose gel stained with Ethidium Bromide $(1 \mu \mathrm{g} / \mathrm{ml})$ and verified 91 using a 100 bp ladder (Vivantis 6x). Following the visualization, PCR band was excised out of 92 the agarose gel and PCR product was purified using PureLink PCR gel clean-up kit (Qiagen) and 
93 quantified using Lambda markers. All 112 samples were sequenced for screening genetic

94 variations using Bigdye terminator chemistry in an ABI 3500 genetic analyzer.

\section{Sequence alignment}

96 All DNA sequences were checked against Caprine genome sequences (BLAST+2.3.0) already

97 published in Genbank and for presence of any insertions, deletions and for absence of stop 98 codons using Sequencher software v 5.0.1 (Gene Codes Corp). Bases ambiguities were 99 visualized and manually edited using CodonCode Aligner 5.1.5 (Codon Code Corporation, 100 Dedham, MA, USA) and heterozygous bases were separated with the aid of PHASE 2.1 101 (Stephens et al., 2001). Poor allelic phase estimates (below Phred20 score) revealed by PHASE 1022.1 were excluded from the analysis.

103 Polymorphic site mining

104 All the aligned sequences for all three gene fragments were realigned with corresponding gene 105 sequences of other Caprine breeds already published in the GenBank database (accession no: 106 L42937.1for GnRHR; X60763 for k-CSN3 and M63868 for LALBA genes) and polymorphic sites 107 were visualized using Sequencher (v 5.3). Haplotypes list was identified using PHASE 2.1 and 108 their frequencies were calculated using Hardy-Weinberg low with the aid of MS Excel 2010. 109 DNA sequences were translated to amino acid sequences using ExPASy translate tool (Gasteiger 110 et al., 2003).

\section{Results and discussion}

112 Three polymorphic sites were identified from GnRHR exon 1 region of non-descript local goats. 113 All three polymorphic sites were heterozygous (Figure 1) and two of the sites were represented 114 by G/A and the other was G/T alleles (Table 1). Heterozygous genotypes found at the 115 polymorphic sites were represented by a minor population of goats while the majority of animals 116 were represented by homozygous genotype. At both G757A and G891T loci $G$ was the 117 predominant allele whereas at locus A730G, A was predominant. The most common haplotype 118 AA, GG, GG was represented by 17 goats out of 31 (57\%). There were two haplotypes (AA, $119 \mathrm{~A} / \mathrm{G}, \mathrm{G} / \mathrm{T}$ and $\mathrm{A} / \mathrm{G}, \mathrm{GG}, \mathrm{GG})$ with similar frequency of occurrence and represented the rarest 120 recombination (3\%). Six possible allelic recombinations were predicted and AGG (74\%) and 121 AAT (1\%) were among the highest and lowest expected haplotypic combinations respectively. 122 From the six predicted haplotypes, five haplotypes (GenBank accession number: KX943532123 KX943536) were carried by the goats analyzed in this study and only AAT combination was not 
124 recorded. Commonly recorded haplotype was AGG (69\%) whereas GGT (2\%) was the rarest 125 among non-descript goats studied (Table 1). Analysis of the deduced amino acid sequences in 126 A730G and G757A sites showed presence of silent mutations and reported G891T variation is 127 non-synonymous (Table 2). Studies by Yang et al., (2011) have reported the same two SNPs at 128 G757A and G891T. To date, the reported synonymous mutation at A730G was not recorded 129 from any goat breed of the world. Boer goats with GG and GT genotypes at G757A and G891T 130 positions respectively showed a significantly positive correlation with the litter size $(\mathrm{p}<0.05)$ 131 (Yang et al., 2011). The present study was aligned with the findings of Yang et al., 2011 by 132 demonstrating the genotype GG (at G891T and G757A). Even a silent mutation can have 133 positive effects on prolificacy by changing the density of GnRHR on the gonadotropes as a result 134 of increased or decreased concentrations of LH and FSH (Schubert et al., 2000).

135 Altogether 13 polymorphic sites were detected from exon 4 and partial intervening region of $k$ 136 CSN3 gene of the studied local goat population. Eleven out of thirteen polymorphic sites were 137 located in exon 4 and two of them were located in intron 4 region (G656A and G657A) hence, 138 are not responsible for amino acid variations of the corresponding peptide chain. Among all the 139 polymorphic sites in exon 4, only 4 of the sites were heterozygous (Figure 2) while 7 other sites 140 were homozygous (Table 2). At all four heterozygous sites the dominant genotype was 141 homozygous and minority of the population was represented by the heterozygous genotype. At 142 A274G and G309A polymorphic sites, all three genotypes (GG, AA, AG) were present and G 143 was the dominant allele (0.525 and 0.9 respectively). At A471G and T591C sites only two 144 genotypes were existed and allele $\mathrm{A}$ and $\mathrm{T}$ were prominent at 0.9 and 0.925 respectively where 145 homozygous recessive genotypes were absent. Genotype GG at A471G and genotype CC at 146 T591C were not recorded. At heterozygous polymorphic sites nine haplotypes were recorded. 147 The most frequent haplotype at heterozygous polymorphic sites was GG/ GG/ AA/ TT (35\%) 148 and represented by 7 animals and was followed by AG/ GG/ AA/ TT (15\%) and AA/ GG/ AA / 149 TT (15\%) haplotypes. Altogether those three genotypes cover $65 \%$ of the variability in the whole 150 population and the remaining $35 \%$ split among other six haplotypes. Nine haplotypic 151 combinations (GenBank accession number: KY003218- KY003226) out of ten predicted allelic 152 haplotypic combinations were present in the studied population of goats. Among them GGAT 153 was the dominant haplotype (23\%) while GAAT (1\%) and GGAC (1\%) were the rarest and 154 GAAC combination was not reported (Table 2). Analysis of the deduced amino acid sequences 
155 showed point mutations at each polymorphic site and all of them were accountable as non156 synonymous variations except for the site T245C and A284G (Table 3). However, to date the 157 nucleotide substitution at 203 site (responsible for transition of $\mathrm{G}$ to $\mathrm{T}$ and Gln to His in 158 nucleotide and amino acid sequences respectively) has not been reported from any goat breed of 159 the world and might be another unique polymorphic site for Sri Lankan indigenous goat 160 population (Table 3). Previous studies have revealed the presence of 16 polymorphic sites within 161 complete exon 4 of $k$-CSN3 gene of domestic goats (Prinzenberg et al., 2005). Thirteen out of 16 162 polymorphic sites were responsible for protein variants and 3 were synonymous mutations 163 (Prinzenberg et al., 2005). From the recorded 11 sites in exon 4, 10 were previously reported by 164 many researches (Angiolillo et al., 2002; Caroli et al., 2001; Jann et al., 2004; Prinzenberg et al., 165 2005; Yahyaoui, 2003 and Yahyaoui et al., 2001) except the novel mutation at G203T.

166 Many researches (Caroli et al., 2001; Prinzenberg et al., 2005; Yahyaoui, 2003 and Yahyaoui et 167 al., 2001) reported the silent mutation at 254 site. Synonymous mutation at 284 site was 168 previously described in Spanish and French Saanen breeds (Yahyaoui et al., 2001) and in seven 169 European breeds (Prinzenberg et al., 2005). Nucleotide A instead of G and G instead of A at 384 170 and 385 were recorded by Prinzenberg et al., 2005 and Angiolillo et al., 2002 in Montefalcone 171 Italian breed. Further, the variabilities at 471, 550, 583 and 591 positions in comparison to 172 accession number X60763 were formerly described in a single paper by Yahyaoui et al., 2001. 173 However, none of the studies have taken attempts to evaluate the possible relationship between 174 reported polymorphism and variations in milk traits of goats.

175 There were no polymorphic sites in partial exon 2 of $L A L B A$ gene studied in local indigenous 176 goats. However, 12 polymorphic sites were there in intron region and were not responsible for 177 amino acid variations. All the mutations found in the intervening region were $A$ to $G$ transitions 178 (Table 4). Within the partial exon 3, a point mutation was recorded by nucleic acid exchange 179 form $\mathrm{T}$ to $\mathrm{C}$ (Figure 3) which intern does not responsible for any transition of amino acid 180 sequence. Eleven polymorphic sites out of thirteen were found as heterozygous sites and only 181 two of the sites were recorded as homozygous (Table 4). The first homozygous site at G1541 182 was an insertion of nucleotide $\mathrm{G}$ compared to the reference sequence M63868 and was 183 represented by all the tested local goats (allelic frequency of 100\%). All the heterozygous sites 184 were characterized only GG (dominant haplotype) and AG haplotypes. Further, G was the 185 dominant allele for all the polymorphic sites investigated by this study except for C1897T site. 
However, genotype AA was not recorded at any heterozygous site within intron 2 and exon 3 regions studied. Total of 35 haplotypic combinations (GenBank accession number: KY003183KY003217) were investigated across exon 2-3 and only five of them were recorded more than once. The most common haplotype (G,G,G,G,G,G,G,G,G,G,G,G,C) was recorded from 22 local animals at a frequency of $36 \%$.

191 The nucleotide exchange reported at exon 2 in this study was previously described (Cosenza et

192 al., 2003 and Lan et al., 2007) and not known to be associated with milk trait. Non-synonymous

193 mutations found in the current study can be used to suggest markers for marker assisted selection 194 after confirming the link between the reported mutation and corresponding traits via association 195 studies along with phenotypic data. Although the synonymous mutations are not directly change 196 the amino acid sequences hence the corresponding trait, this type of mutations may be still 197 important as effective genetic markers for association analysis (Thomas et al., 2011). However, 198 markers based on recorded novel polymorphic sites will be reliable tool for genotypic 199 characterization of local goats in Sri Lanka.

200 Since non-descript goats represent a highly localized population, it is apparent to observe an 201 inbred population. However, exonic regions examined in current study revealed the presence of 5 202 combined haplotypes out of 6 predicted and 9 combined haplotypes out of 10 predicted 203 haplotypes in GnRHR and $k$-CSN3 respectively and their observed frequencies are not much 204 deviated from the expected (Table 1 and 2). The reported intronic diversity in LALBA gene was 205 also high and in turn this suggests that, they are currently not representing an inbred population. 206 Further, the non-descript goats were previously noted as a phenotypically heterogeneous 207 population while the significant genetic diversity reported in this study revealed their genetic 208 heterogeneity as well. The genotypes and haplotypes which were not reported in the studied 209 population may be attributed to low production frequency of those haplotypes where their 210 expected haplotypic frequencies were also low and or low sample size. Although they were 211 declared as a threated population of goats owing to indiscriminate cross breeding, the newly 212 recorded polymorphic sites in GnRHR and k-CSN3 genes evident that they still possess preserved 213 local genetic resources within the genome.

\section{Conclusions}

215 This study is a preliminary report on SNPs in $k-C S N 3, L A L B A$ and GnRHR genes of non-descript 216 local goats in Sri Lanka. Results of the current study reveal genetic variability of Sri Lankan 
217 non-descript goats reporting; absolutely novel polymorphic sites (at G203T and A730G for $k$ -

218 CSN3 and GnRHR genes respectively) and 9 out of 10 and 5 out of 6 combined haplotypes in

219 above genes. These novel SNPs will be extremely important in genetic characterization of non-

220 descript local goats and other mutations found in this study can be utilized to indicate molecular

221 markers to be used in marker assisted selection and association analyses. Further studies would

222 be essential to evaluate physiological role of different genetic haplotypes found in the current

223 study in relation to production traits of non-descript goats in Sri Lanka.

\section{Acknowledgment}

225 We would like to thank National Science Foundation competitive research grant (RG/2011/BT/

226 11), Sri Lanka and University of Peradeniya research grants (RG/2011/57/V and RG/2012/CG-

227 3/52/V) for financial support and IAEA TC project: (SLR/5/41) for technical assistance. The

228 authors also like to acknowledge the support of D.C.A. Gunawardena and staff of Veterinary

229 Research Institute, Sri Lanka.

230 References

231 An, X.P., Han, D., Hou, J. X., Li, G., Wang, J.G., Yang, M.M., Song, Y.X., Zhou, G.Q., Wang,

232 Y.N., Ling, L., Yan, Q.M., Cao, B.Y., 2009. GnRHR gene polymorphisms and their effects on

233 reproductive performance in Chinese goats. Small Ruminant Research 85, 130-134.

234 Angiolillo, A., Yahyaoui, M.H., Sanchez, A., Pilla, F., Folch, J.M., 2002. Short communication:

235 Characterization of a new genetic variant in the caprine $\kappa$-casein gene. Journal of Dairy Science.

$23685,2679-2680$.

237 Azevedo, J., Mascarenhas, M., Valentim, R., Almeida, J., Silva, S., Pires, S., Teixeira, M., 1994.

238 Preservação e valorização dos ovinos da raça Churra da Terra Quente. Relatório Final do

239 Projecto PAN I da Associação Nacional de Criadores de Ovinos Churra da Terra Quente, Torre

240 de Moncorvo, Portugal.

241 Cargill, M., Altshuler, D., Ireland, J., Sklar, P., Ardlie, K., Patil, N., Shaw, N., Lane, C. R., Lim,

242 E.P., Kalyanaraman, N., Nemesh, J., Ziaugra, L., Friedland, L., Rolfe, A., Warrington,

243 J., Lipshutz, R., Daley, G.Q., Lander, E. S., 1999. Characterization of single-nucleotide

244 polymorphisms in coding regions of human genes. Nature Genetics. 22(3), 231-238.

245 Caroli, A., Jann, O., Budelli, E., Bolla, P., Jager, S., Erhardt, G., 2001. Genetic polymorphism of 246 goat $\kappa$-casein (CSN3) in different breeds and characterization at DNA level. Animal Genetics.

247 32, 226-230. 
Chiatti, F., Chessa, S., Bolla P., Cigalino, G., Caroli, A., Pagnacco, G., 2005. Effect of the $\kappa-$ casein polymorphism on milk composition in the Orobica goat. Journal Dairy Science. 90, 19622501966.

251 Clement, M., Posada, D. and Crandall, K.A. (2000). TCS: a computer program to estimate gene 252 genealogies. Molecular Ecology 9, 1657-1660.

253 Cosenza, G., Gallo, D., Illario, R., Gregorio, P., Senese, C., Ferrara, L., Ramunno, L., MvaI, A., 254 2003. PCR-RFLP detecting a silent allele at the goat $\alpha$-lactalbumin locus. Journal of Dairy 255 Research 70, 355-357.

256 Gasteiger, E., Gattiker, A., Hoogland, C., Ivanyi, I., Appel, R.D., Bairoch, A., 2003. ExPASy: the proteomics server for in-depth protein knowledge and analysis. Nucleic Acids Research 31, $258 \quad 3784-3788$.

259 Jain, A., Gour, D.S., Bisen, P.S., Dubey, P.P., Sharma, D.K., Joshi, B.K., Kumar, D., 2009.

260 Single nucleotide polymorphism (SNP) in alpha-lactalbumin gene of Indian Jamnapari breed of 261 Capra hircus. Small Ruminant Research 82(2),156-160.

262 Jann, O.C., Prinzenberg, E.M., Luikart, Caroli, A., Erhardt, G., 2004. High polymorphism in the 263 kappa-casein (CSN3) gene G. from wild and domestic caprine species revealed by DNA 264 sequencing. Journal of Dairy Research. 71,188-195.

265 Jawdat, N.G., Adnan, F.N., Akeel, H.A., 2011. Simple salting-out method for genomic DNA 266 extraction from whole blood. Tikrit Journal of Pure Science. 16,9-11.

267 Kiplagat, S.K., Agaba, M., Kosgey, I.S., Okeyo, M., Indetie, D., Hanotte, O., Limo, M.K., 2010.

268 Genetic polymorphism of kappa-casein gene in indigenous Eastern Africa goat populations.

269 International Journal of Genetics and Molecular Biology. 2,001-005.

270 Lan, X.Y., Pan, C.Y., Chen, H., Zhang, C.L., Zhang, A.L., Zhang, L., Li, J.Y., Lei, C.Z., 2007.

271 An MspI PCR-RFLP detecting a single nucleotide polymorphism at alpha-lactalbumin gene in 272 goat. Czech Journal of Animal Science 52(5), 138-142.

273 Marletta, D., Criscione, A., Bordonaro, S., Guastella, A.M., D’Urso, G., 2007. Casein

274 polymorphism in goat's milk. Lait. 87,491-504.

275 Ming-Xing, C., Jie-Wen, X., Di Ran, Xue-Wei, L., Li, F., Yue-Hui, M., Kui, L., 2009.

276 Polymorphism of gonadotropin releasing hormaone receptor (GnRHR) gene and its relationship 277 with prolificacy of lining grey goat. Journal of Agricultural Biotechnology. 17(2), 218-223. 
278 National Livestock Breeding Policy Guidelines and Strategies for Sri Lanka (2010). Ministry of 279 Livestock and Rural Community Development, Colombo. http://www.fao.org/3/a-bc260e.pdf $280 \quad$ (accessed 10. 01.2016)

281 Prinzenberg, E.M., Gutscher, K., Chessa, S., Caroli, A., Erhardt, G., 2005. Caprine א-Casein 282 (CSN3) Polymorphism: New Developments in Molecular Knowledge. Journal of Dairy Science. $28388,1490-1498$.

284 Schubert, U., Anton, L.C., Gibbs, J., Norbury, C.C., Yewdell, J.W., Bennink, J.R., (2000). Rapid 285 degradation of a large fraction of newly synthesized proteins by proteasomes. Nature. 404,770286774.

287 Silva, P., 2010. Indigenous Animal Genetic Resources of Sri Lanka - Status, potential and 288 opportunities. GEF-UNEP-ILRI-FAnGr Asia Project, University of Peradeniya, Sri Lanka. 289 Stephens, M., Smith, N.J., Donnelly, P., 2001. A new statistical method for haplotype 290 reconstruction from population data. American Journal of Human Genetics. 68, 978-989.

291 Thomas, P.E., Klinger, R., Furlong, L.I., Hofmann-Apitius, M., Friedrich, C.M. (2011).

292 Challenges in the association of human single nucleotide polymorphism mentions with unique 293 database identifiers. BMC Bioinformatics. 12(4),1186-1471.

294 Yahyaoui, M.H., A, Coll, A., Sanchez, Folch, J.M., 2001. Genetic polymorphism of the caprine 295 kappa casein gene. Journal of Dairy Research. 68,209-216.

296 Yahyaoui, M.H., 2003. Genetic polymorphism in goats. PhD Thesis, Bellaterra, Spain.

297 Yang, K., Zhang, C., Xu, D., Wen, Q., Yang, L., 2011. Polymorphism of the GnRHR gene and 298 its association with litter size in Boer goats. South African Journal of Animal Science. 41, 398299402.

300 Zidi, A., Casas, E., Amills, M., Jordana, J., Carrizosa, J., Urrutia, B., Serradilla, J.M., 2014.

301 Genetic variation at the caprine lactalbumin, alpha (LALBA) gene and its association with milk 302 lactose concentration. Stichting International Foundation for Animal Genetics. 45, 609-613. 


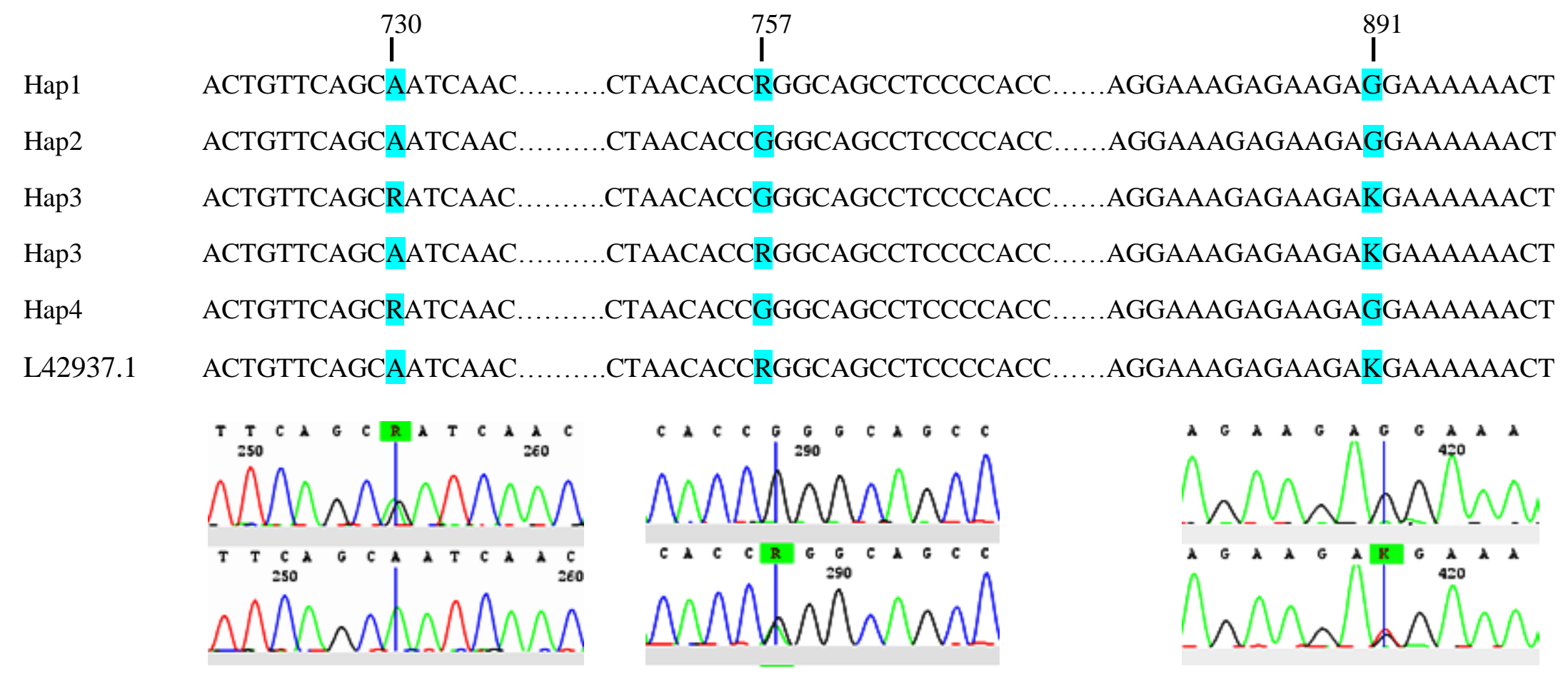

Figure 1 Sequence alignment of GnRHR gene fragment compared to GenBank accession no. L42937.1 
Hap1 ATAGTCAATT. .AAAGCCAGTTGCAGTTAGGT

Hap2 ATARTCAATT. .AAAGCCAGTTGCAGTTAGGT ACAGAAATCCC

1

Hap3 ATAATCAATT .AAAGCCARTTGCAGTTAGGT .ACAGAAATCCC TGCGAGTGCATCTGAGACCAA

Hap4 ATAATCAATT. .AAAGCCAATTGCAGTTAGGT ..ACAGAAATCCC TGCGAGTGCATCTGAGACCAA Hap5 ATAATCAATT. .AAAGCCAGTTGCAGTTAGGT ACAGAARTCCC TGCGAGTGCAYCTGAGACCAA

Hap6 ATARTCAATT .AAAGCCAGTTGCAGTTAGGT ..ACAGAARTCCC .TGCGAGTGCAYCTGAGACCAA

Hap7 ATAGTCAATT. .AAAGCCAGTTGCAGTTAGGT ACAGAARTCCC TGCGAGTGCATCTGAGACCAA

Hap8 ATAATCAATT. .AAAGCCAGTTGCAGTTAGGT ACAGAARTCCC TGCGAGTGCATCTGAGACCAA

Hap9 ATARTCAATT. AAAGCCARTTGCAGTTAGGT ACAGAAATCCC GCGAGTGCATCTGAGACCAA

X60- ATAATCAATT. .AAAGCCAGTTGCAGTTAGGT ACAGAAGTCCC TGCGAGTGCAYCTGAGACCAA $-763$

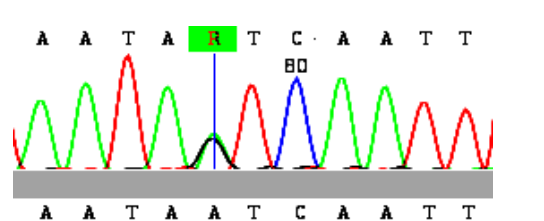
An Ho wheresh

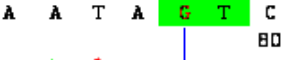
AMAMWAMA
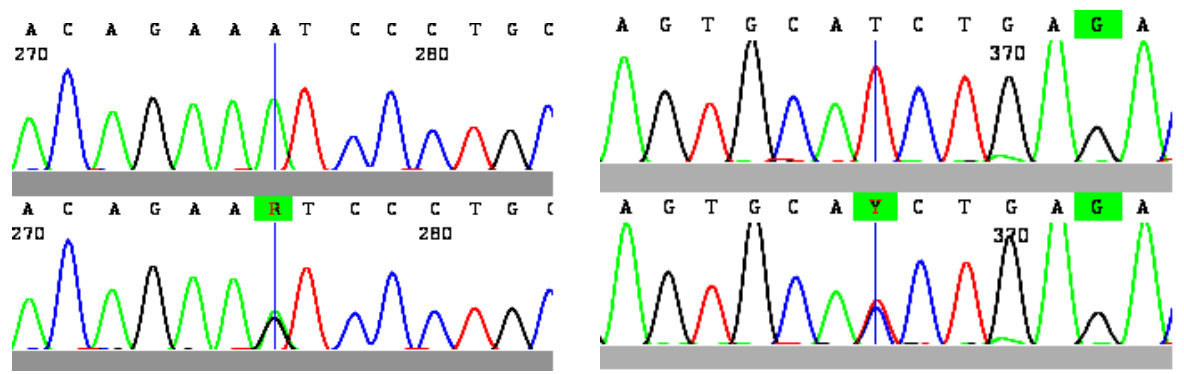

Figure 2 Sequence alignment of $k$-CSN3 gene fragment compared to GenBank accession no. X60763 


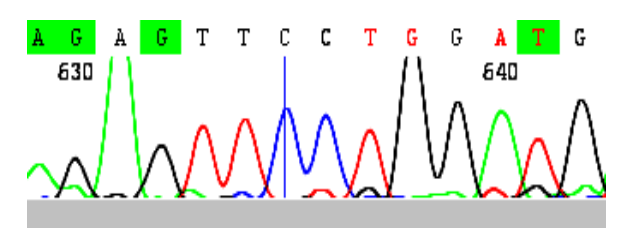

Figure 3 Sequence alignment of LALBA gene fragment compared to GenBank accession no. KF781121.1 
Table 1. The allelic and genotypic frequencies, recombined genotypic and haplotypic frequencies for the polymorphism in exon 1 of $G n R H R$ gene in non-descriptive goats in Sri Lanka

\begin{tabular}{|c|c|c|c|}
\hline Locus & Genotype & $\begin{array}{l}\text { Genotype } \\
\text { Frequency }\end{array}$ & $\begin{array}{l}\text { Allele/Haplotype } \\
\text { frequency (EF. } \pm \text { SD.) }\end{array}$ \\
\hline \multirow{2}{*}{ A730G } & AA (26) & 0.87 & A 0.93 \\
\hline & AG (04) & 0.13 & G 0.07 \\
\hline \multirow{2}{*}{ G757A } & GG (23) & 0.77 & G 0.88 \\
\hline & GA (07) & 0.23 & A 0.12 \\
\hline \multirow{2}{*}{ G891T } & GG (24) & 0.80 & G 0.90 \\
\hline & GT (06) & 0.20 & Т 0.10 \\
\hline Haplotypes & $\begin{array}{l}\text { AA,A/G,GG (07) } \\
\text { AA,GG,GG (17) } \\
\text { A/G,GG,G/T (04) } \\
\text { AA,A/G,G/T (01) } \\
\text { A/T,GG,GG (01) }\end{array}$ & $\begin{array}{l}0.24 \\
0.57 \\
0.13 \\
0.03 \\
0.03\end{array}$ & $\begin{array}{l}\text { AAG } 0.15(0.13 \pm 0.014) \\
\text { AGG } 0.69(0.74 \pm 0.035) \\
\text { AGT } 0.02(0.04 \pm 0.014) \\
\text { GGG } 0.12(0.05 \pm 0.049) \\
\text { GGT } 0.02(0.03 \pm 0.001) \\
\text { AAT NR }(0.01)\end{array}$ \\
\hline
\end{tabular}

EF; Expected frequency of combined haplotypes, SD; Standard deviation, NR; Not recorded 
Table 2. The allelic and genotypic frequencies, recombined genotypic and haplotypic frequencies at the heterozygous polymorphism sites in exon 4 of $k$-CSN3 gene in non-descriptive goats in Sri Lanka

\begin{tabular}{|c|c|c|c|}
\hline Locus & Genotype & $\begin{array}{l}\text { Genotype } \\
\text { frequency }\end{array}$ & $\begin{array}{l}\text { Allele/Haplotype } \\
\text { frequency (EF. } \pm \text { SD.) }\end{array}$ \\
\hline \multirow[t]{3}{*}{ A274G } & GG (9) & 0.45 & G 0.525 \\
\hline & AA (8) & 0.4 & A 0.475 \\
\hline & $\mathrm{A} / \mathrm{G}(3)$ & 0.15 & \\
\hline \multirow[t]{3}{*}{ G309A } & GG (17) & 0.85 & G 0.9 \\
\hline & $\mathrm{AA}(1)$ & 0.05 & A 0.1 \\
\hline & $\mathrm{A} / \mathrm{G}(2)$ & 0.1 & \\
\hline \multirow[t]{2}{*}{ A471G } & AA (16) & 0.8 & A 0.9 \\
\hline & $\mathrm{A} / \mathrm{G}(4)$ & 0.2 & G 0.1 \\
\hline \multirow[t]{2}{*}{ T591C } & TT (17) & 0.85 & T 0.925 \\
\hline & $\mathrm{C} / \mathrm{T}(3)$ & 0.15 & $\mathrm{C} 0.075$ \\
\hline \multirow[t]{10}{*}{ Haplotype } & GG/GG/AA/TT (7) & 0.35 & GGAT $0.23(0.47 \pm 0.168)$ \\
\hline & AG/GG/AA/TT(3) & 0.15 & AGAT $0.19(0.30 \pm 0.082)$ \\
\hline & AA/AG/AA/CT (1) & 0.05 & AAAC $0.18(0.07 \pm 0.078)$ \\
\hline & $\mathrm{AA} / \mathrm{AA} / \mathrm{AA} / \mathrm{CT}(1)$ & 0.05 & AGAC $0.13(0.02 \pm 0.078)$ \\
\hline & AA/GG/AA/TT (3) & 0.15 & AAAT $0.13(0.02 \pm 0.078)$ \\
\hline & AG/GG/AG/TT (1) & 0.05 & AGGT $0.06(0.06 \pm 0.001)$ \\
\hline & GG/GG/AG/TT (1) & 0.05 & GGGT $0.06(0.03 \pm 0.015)$ \\
\hline & AA/GG/AG/TT (2) & 0.1 & GAAC NR $(0.01)$ \\
\hline & $\mathrm{AG} / \mathrm{AG} / \mathrm{AA} / \mathrm{CT}(1)$ & 0.05 & GAAT $0.01(0.01 \pm 0.002)$ \\
\hline & & & GGAC $0.01(0.01 \pm 0.002)$ \\
\hline
\end{tabular}

EF; Expected frequency of combined haplotypes, SD; Standard deviation, NR; Not recorded 
Table 3. $k$-CSN3 (exon 4) and GnRHR (exon 1) genetic variability among locally adapted goats in Sri Lanka

\begin{tabular}{|c|c|c|c|c|c|c|c|c|c|c|c|c|c|c|c|}
\hline \multirow{2}{*}{$\begin{array}{l}\text { GenBank } \\
\text { accession } \\
\text { no./ } \\
\text { Reference }\end{array}$} & \multicolumn{11}{|c|}{ Nucleotide Position in $k$-CSN3 gene } & \multirow{2}{*}{$\begin{array}{l}\text { GenBank } \\
\text { accession } \\
\text { no./ } \\
\text { Reference }\end{array}$} & \multicolumn{3}{|c|}{$\begin{array}{c}\text { Nucleotide Position in GnRHR } \\
\text { gene }\end{array}$} \\
\hline & ڤి & $\stackrel{n}{\sim}$ & $\stackrel{\Delta}{\Delta}$ & d & oे & $\underset{n}{+\infty}$ & $\ddot{\infty}$ & $\bar{z}$ & $\stackrel{\circ}{n}$ & $\underset{\infty}{\infty}$ & $\bar{n}$ & & 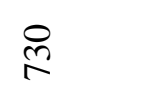 & $\sqrt[n]{n}$ & $\bar{\infty}$ \\
\hline X60763 & $\mathrm{G}(\mathrm{Q})$ & $\mathrm{T}(\mathrm{Y})$ & $\mathrm{A}(\mathrm{N})$ & G(L) & $\mathrm{G}(\mathrm{V})$ & $\mathrm{G}(\mathrm{D})$ & $\mathrm{A}(\mathrm{D})$ & $\mathrm{G}(\mathrm{V})$ & $\mathrm{T}(\mathrm{V})$ & $\mathrm{C}(\mathrm{A})$ & $\mathrm{T}(\mathrm{S})$ & $\begin{array}{l}\text { Yang et al, } \\
2011\end{array}$ & - & $\mathrm{A} / \mathrm{G}(\mathrm{P})$ & $\mathrm{G} / \mathrm{T}(\mathrm{R} / \mathrm{M})$ \\
\hline AF485340 & & & & & & & & $\mathrm{A}(\mathrm{I})$ & & & & This study & $\mathrm{A}(\mathrm{A})$ & & $\mathrm{G}$ \\
\hline AY090466 & & $\mathrm{C}(\mathrm{Y})$ & & & & & $\mathrm{G}(\mathrm{G})$ & $\mathrm{A}$ & & & $\mathrm{C}(\mathrm{P})$ & This study & A & $\mathrm{G}$ & $\mathrm{G}$ \\
\hline AF521022 & & & $\mathrm{G}(\mathrm{S})$ & & & & & A & & & & This study & $\mathrm{A} / \mathrm{G}(\mathrm{A})$ & $\mathrm{G}$ & \\
\hline AY350425 & & $\mathrm{C}$ & & $\mathrm{A}(\mathrm{L})$ & $\mathrm{A}(\mathrm{I})$ & & & A & & $\mathrm{T}(\mathrm{V})$ & & This study & A & & \\
\hline AY428577 & & $\mathrm{C}$ & & & & $\mathrm{A}(\mathrm{N})$ & & A & $\mathrm{C}(\mathrm{A})$ & & & This study & $\mathrm{A} / \mathrm{G}$ & $\mathrm{G}$ & $\mathrm{G}$ \\
\hline This study & $\mathrm{T}(\mathrm{H})$ & & $\mathrm{G}$ & & & & & $\mathrm{A}$ & & & & & & & \\
\hline This study & $\mathrm{T}$ & & $\mathrm{A} / \mathrm{G}$ & & & & & A & & & & & & & \\
\hline This study & $\mathrm{T}$ & & & & $\mathrm{A} / \mathrm{G}$ & & & A & & & $\mathrm{C} / \mathrm{T}$ & & & & \\
\hline This study & $\mathrm{T}$ & & & & $\mathrm{A}$ & & & A & & & $\mathrm{C}$ & & & & \\
\hline This study & $\mathrm{T}$ & & & & & & & A & & & & & & & \\
\hline This study & $\mathrm{T}$ & & $\mathrm{A} / \mathrm{G}$ & & & & & $\mathrm{A} / \mathrm{G}$ & & & & & & & \\
\hline This study & $\mathrm{T}$ & & $\mathrm{G}$ & & & & & $\mathrm{A} / \mathrm{G}$ & & & & & & & \\
\hline This study & $\mathrm{T}$ & & & & & & & $\mathrm{A} / \mathrm{G}$ & & & & & & & \\
\hline This study & $\mathrm{T}$ & & $\mathrm{A} / \mathrm{G}$ & & $\mathrm{A} / \mathrm{G}$ & & & A & & & $\mathrm{C} / \mathrm{T}$ & & & & \\
\hline
\end{tabular}

Q; Gln, Y; Tyr, N; Asn, L; Leu, V; Val, D; Asp, A; Ala, S; Ser, H; His, I; Ile P; Pro, G; Gly, A; Ala, P; Pro, R;Arg and M; Met. kCSN3 nucleotide positions are compared to reference GenBank accession no X60763 and GnRHR nucleotides positions are compared to GenBank accession no L42937.1. Note; only the nucleotide and amino acid variations compared to reference are indicated in the table 
Table 4 LALBA (intron 2 and part of exon 3) genetic variability among locally adapted goats in Sri Lanka

Nucleotide position

\begin{tabular}{|c|c|c|c|c|c|c|c|c|c|c|c|c|c|}
\hline $\begin{array}{l}\text { GenBank accession } \\
\text { no. }\end{array}$ & & & & & & & & & & & & & \\
\hline M63868 & $\mathrm{G}$ & - & $\mathrm{G}$ & $\mathrm{G}$ & $\mathrm{G}$ & $\mathrm{G}$ & $\mathrm{G}$ & $\mathrm{G}$ & G & $\mathrm{G}$ & $\mathrm{G}$ & G & $\mathrm{C}(\mathrm{F})$ \\
\hline KF781121.1 & $\mathrm{G}$ & $\mathrm{G}$ & $\mathrm{G}$ & G & $\mathrm{G}$ & $\mathrm{G}$ & $\mathrm{G}$ & $\mathrm{G}$ & G & $\mathrm{G}$ & $\mathrm{G}$ & G & $\mathrm{T}(\mathrm{F})$ \\
\hline This study & $\begin{array}{l}\mathrm{G} \\
\mathrm{A} / \mathrm{G}\end{array}$ & $\begin{array}{l}\mathrm{G} \\
\mathrm{G}\end{array}$ & $\begin{array}{l}\mathrm{G} \\
\mathrm{A} / \mathrm{G}\end{array}$ & $\begin{array}{l}\text { G } \\
\mathrm{A} / \mathrm{G}\end{array}$ & $\begin{array}{l}\mathrm{G} \\
\mathrm{A} / \mathrm{G}\end{array}$ & $\begin{array}{l}\mathrm{G} \\
\mathrm{A} / \mathrm{G}\end{array}$ & $\begin{array}{l}\mathrm{G} \\
\mathrm{A} / \mathrm{G}\end{array}$ & $\begin{array}{l}\mathrm{G} \\
\mathrm{A} / \mathrm{G}\end{array}$ & $\begin{array}{l}\text { G } \\
\mathrm{A} / \mathrm{G}\end{array}$ & $\begin{array}{l}\mathrm{G} \\
\mathrm{A} / \mathrm{G}\end{array}$ & $\begin{array}{l}\mathrm{G} \\
\mathrm{A} / \mathrm{G}\end{array}$ & $\begin{array}{l}\text { G } \\
\mathrm{A} / \mathrm{G}\end{array}$ & $\mathrm{C}(\mathrm{F})$ \\
\hline
\end{tabular}

F; Phe. Nucleotide positions are compared to GenBank accession no M63868. Note; only the nucleotide and amino acid variations compared to reference are indicated in the table 